\title{
Solar Radiation Projections of Cmip5 Models for South of Brazil
}

\author{
* Elison Eduardo Bierhals ', Francisco Pereira ${ }^{2}$, Claudinéia Brazil ${ }^{3}$, Elton Rossini ${ }^{4}$ \\ 1, 2, 3, 4 Energy Engineering, State University of Rio Grande do Sul, Brazil \\ 1E mail: bierhalseduardo@gmail.com ,2E mail: kiko.borgesp@gmail.com ,3E mail: neiabrazil@gmail.com
}

\begin{tabular}{l}
\hline A R T I C L E I N F O: \\
\hline Article history: \\
Received 15 September 2017 \\
Accepted 25 October 2017 \\
Available online 3 November \\
2017 \\
\hline Keywords: \\
Climate Change; \\
Solar Radiation; \\
Energy Utilization.
\end{tabular}

This work is licensed under a Creative Commons Attribution

NonCommercial - NoDerivs 4.0. "CC-BY-NC-ND"

\begin{abstract}
A B S T R A C T
The most critical factors in the acceleration of climate and environmental changes are related to the industrial development and consequently to an increase in the demand for electricity. Looking for measures that minimize impacts to the environment, alternative energy sources are gaining more and more space in the Brazilian energy matrix. Brazil presents a great solar potential for the generation of electric energy, so the knowledge of solar radiation and its characteristics are fundamental for the study of the energy use. Due to the above, this article aims to verify the climatic variability corresponding to the variations in solar radiation patterns, in the face of climate change scenarios. The database used in this research is part of the Phase 5 Intercomparison of Matching Models (CMIP5). Was used the RCP 8.5 that scenario is considered the most pessimistic for the 21 st century and is consistent with no policy change to reduce emissions and strong dependence on fossil fuels. It is important, first of all, to determine its availability in order to enable the use of solar radiation as a source of energy in a given location and / or region. The climatic projections, based on the pessimistic scenario, in a 75-year period (20262100 ) showed a fall in solar radiation in all of Rio Grande do Sul, reaching $12 \%$ in the eastern region of the state. A concern with the factors that influence the pessimistic perspectives of this scenario, as it may affect a possible production of electric energy from solar radiation.

JOURNAL OF CONTEMPORARY URBAN AFFAIRS (2017) 1(3), 1-6.
\end{abstract}

https://doi.org/10.25034/ijcua.2018.36xx71

www.ijcua.com

Copyright (C) 2017 Journal Of Contemporary Urban Affairs. All rights reserved.

\section{Introduction}

The acceleration of climate change is related to the industrial development and, consequently, to an increase in the demand for electricity. Looking for measures that minimize environmental impacts, the Brazilian energy matrix is gaining new formatting, becoming less and less dependent on non-renewable energy sources, such as oil and natural gas, while alternative sources of renewable energy increase its presence (Lima, 2012). By opting for a photovoltaic solar generation, the consumer also contributes to the mitigation of climate change, which is currently considered one of the biggest environmental problems.

The IPCC (Intergovernmental Panel on Climate Change) is the leading international scientific body for assessing climate change and

*Corresponding Author:

Energy Engineering, State University of Rio Grande do Sul, Brazil

E-mail address: bierhalseduardo@gmail.com 
was created to provide scientific information on the current state of knowledge of climate change and its possible socioeconomic and environmental impacts (Silveira et al., 2016).

The results from this program have been an important tool for policies implementation as responses to climate change. The data are the results of global models simulations from several research centers, simulations of global models represent numerical and physical approximations of equations governing the movements of the atmosphere and their interaction with the Earth's surface (Sousa, 2010).

Since 1995, the IPCC reports have had an experimental framework to study the data provided by ocean-atmosphere general circulation models, the Coupled Model Intercomparison Project (CMIP). The combination of several readings of atmospheric data around the world makes it possible to evaluate certain patterns, which can predict events or evaluate deficiencies or even errors in the ways of analyzing these data (Le Treut et al., 2007) .

The use of alternative sources of energy represents a major challenge in order to meet energy demand and reduce environmental damage. Faced with the need to diversify the energy matrix and try to minimize global warming, solar energy has been gaining space, being an important renewable source, even depending on the climatic conditions.

Compared to the European level, Brazil presents a great solar potential for the generation of electric energy, having more sun hours per year. The sun is an inexhaustible source of energy, allowing you to obtain a clean energy. According to Freitas (2008) quality information about the solar resource is fundamental for the sizing of solar systems, since the generation of electric energy depends on the availability of the resource.

Therefore, the knowledge about solar radiation and its characteristics are fundamental for the study of the energy utilization. Due to the above, this article aims to verify the climatic variability corresponding to the variations in solar radiation patterns by analyzing climate change scenarios.

\section{Materials And Methods}

\subsection{Study area}

The state of Rio Grande do Sul (Figure 1) is located in Brazil's extreme south, between latitudes $27^{\circ}$ and $34^{\circ}$ South (S) and longitudes $50^{\circ}$ and $57^{\circ}$ West (W). The state maintains borders to the West with Argentina, to the South with Uruguay, to the North with the Brazilian State of Santa Catarina and to the east, it is bathed by the Atlantic Ocean.

The territorial area of Rio Grande do Sul has $268,781,896 \mathrm{~km}^{2}$; the average population density is 38 inhabitants per $\mathrm{km}^{2}$. Among the states of Brazil's southern region is the one with the lowest density (Gross, 2015).

The predominant climate is subtropical, being that in the region of the upper plateau the climate is subtropical of altitude.
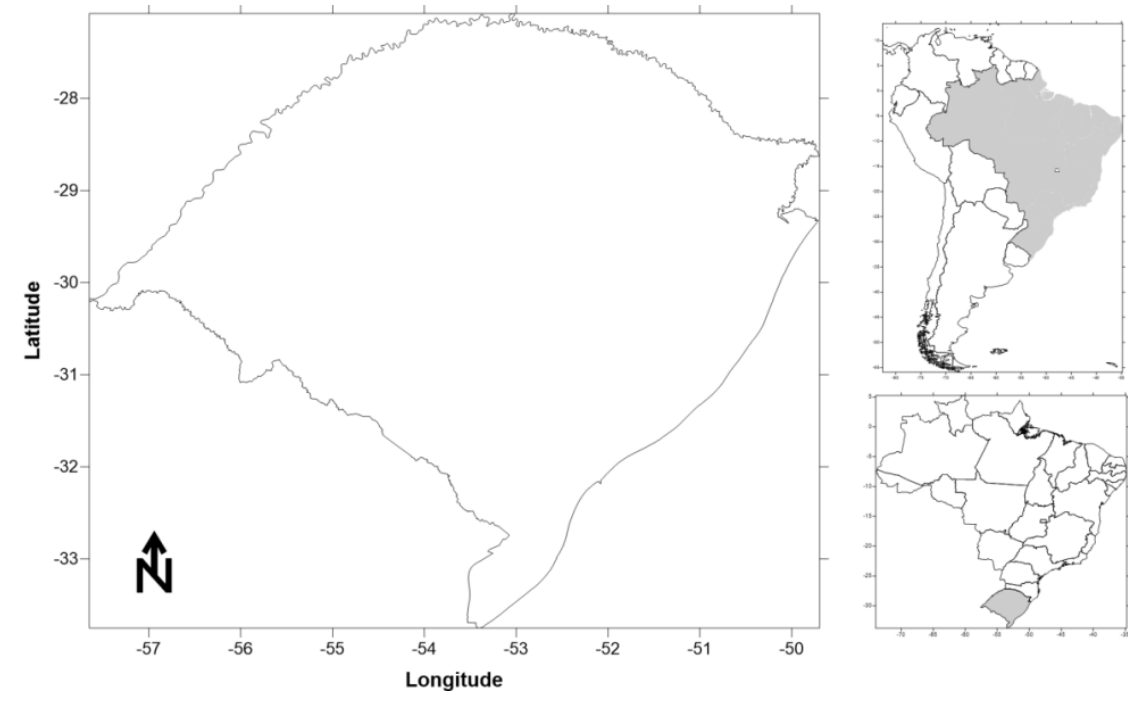

Figure 1. Map of the Study Region. 


\subsection{Description of the model used}

The database used in this research is a part from the Phase 5 Intercomparison of Matching Models (CMIP5), and contributed to the preparation of the fifth IPCC-AR5 report. The data were extracted from ACCESS (The Australian Community Climate and Earth System Simulator) model.

According to Van Vuuren, and others in AR5 the scenarios are organized according to the RCPs. In this research, RCP 8.5 scenario was used which represents a scenario with a continuous population growth, resulting in high carbon dioxide emissions, with an increase Up to $4^{\circ} \mathrm{C}$. (Van Vuuren, et al., 2011)

In terms of greenhouse gas emissions, this scenario is considered to be the most pessimistic for the 21st century and is consistent with no policy change to reduce emissions and strong dependence on fossil fuels (Silveira, et al., 2016).

\section{Methodology}

The work was carried out in steps, the monthly data of Solar radiation in $\mathrm{KWh} / \mathrm{m}^{2}$ were extracted from the IPCC-AR5 data base, this work stage was performed through GRADS software (Grid Analysis and Display System ). Grads is a data visualization and analysis systems in grid points, working with binary data matrices, in which variables can have up to four dimensions (longitude, latitude, vertical levels and time) (Souza, 2004).

After this stage, the historical data series and the data series with the climatic projections were organized. The projections were divided into three scenarios: Scenario-1 (2026-2050), Scenario-2 (2051-2075) and Scenario-3 (20762100).

The solar radiation anomaly was calculated from the following equation:

$A_{\text {Rad }}(\%)=\left(\left(R_{M M}-R_{M N}\right) / R_{M N}\right)^{*} 100 \quad$ (Equation 1) At where:

ARad (\%) is the radiation anomaly in percentage;

RMM is the average radiation of the month analyzed;

NMR is the normal climatological correlation for the analyzed month.

The World Meteorological Organization (WMO) defines climatological normal as averages of climatological data calculated for consecutive periods of 30 years

\section{Results And Discussions}

It is important, first of all, to determine its availability in order to enable the use of solar radiation as a source of energy in a given location and / or region.

Figure 3 shows the average solar radiation based on the IPCC projections for the state of Rio Grande do Sul from 2026 to 2100. The highest values are found in the Rio Grande do Sul'sthe western half of the state of Rio Grande do Sul, in the region of the Uruguayan's municipality with the maximum around $5 \mathrm{KWh} / \mathrm{m}^{2}$, agreeing with the results obtained by Buriol and others that verified the availability of solar radiation from historical data. In the state's eastern region are located the lowest values of solar radiation (Buriol, et. al., 2012).

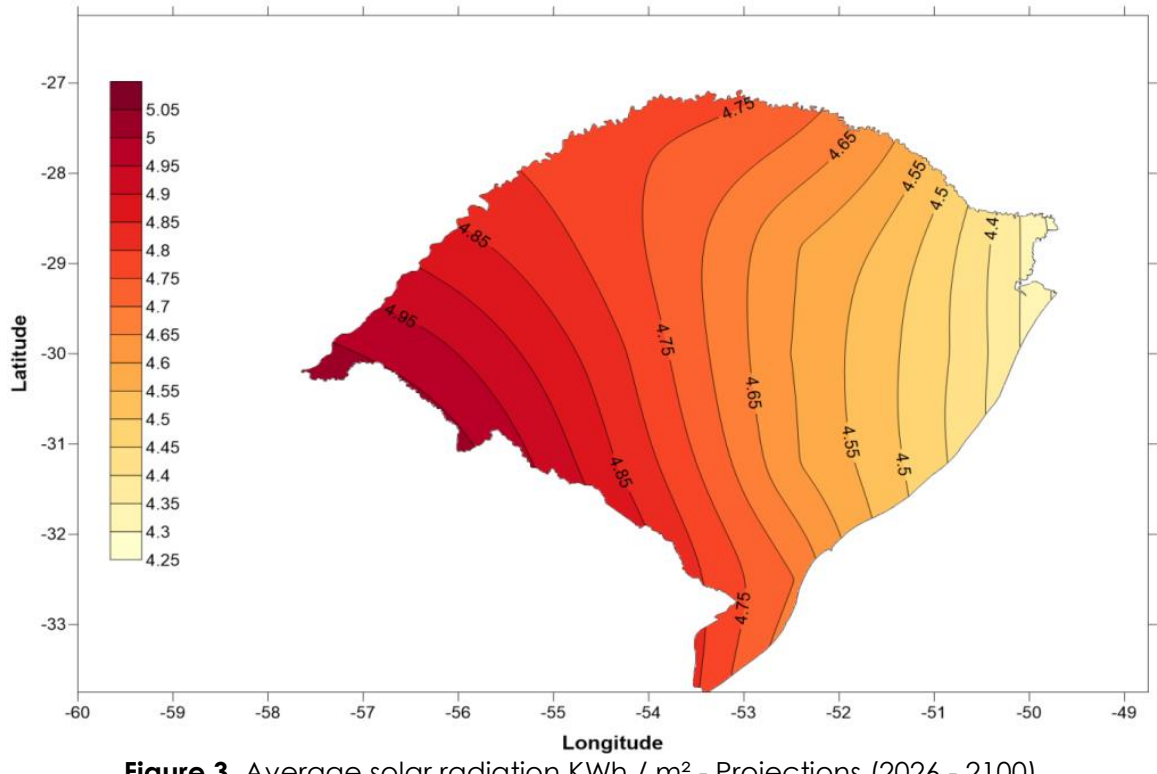

Figure 3. Average solar radiation $\mathrm{KWh} / \mathrm{m}^{2}$ - Projections (2026 - 2100)

From the historical series of Solar Radiation, the Climatic Radiation Norms were calculated, which are the long period averages of 1961-1990, for all months of the year. Based on 
this information were recorded for each period the percentage of months that the Radiation was above or below Normal Climatological, according to Figure 4, it was verified that for all the scenarios analyzed Solar Radiation has a tendency to decrease over the next few years, in the scenario of 2076-2100 the tendency is that the radiation is $60 \%$ of the months below the normal climatological.

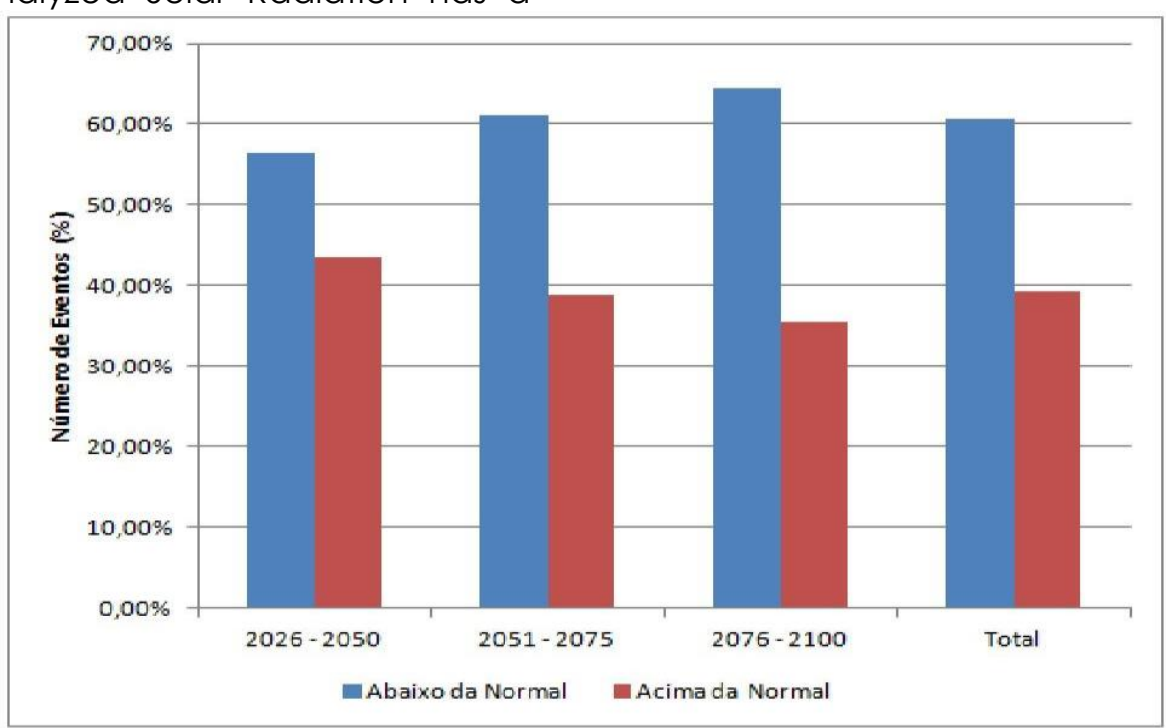

Figure 4. Graph percentage of number of events above(red) and below(blue) the Normal Climatological.

In order to verify the mean alteration trend over time, the anomalies of solar radiation that are the extreme fluctuations related to the historical averages were analyzed. Figure 5 shows the solar radiation anomaly for scenario 1 (2026-2100). In the coastal region, in addition to presenting the lowest values of solar radiation, the trend is that for this scenario there will be a fall around 5\% compared to historical data, verifying the scenario 2(Figure 6) and scenario 3 (Figure 7), the tendency is to increase the fall of solar radiation, reaching a loss of $12 \%$ in the upper region of the East of the state of Rio Grande do Sul.

In general, negative anomalies were observed in the three scenarios, indicating a significant fall in radiation over the years, for the entire Gaucho territory.

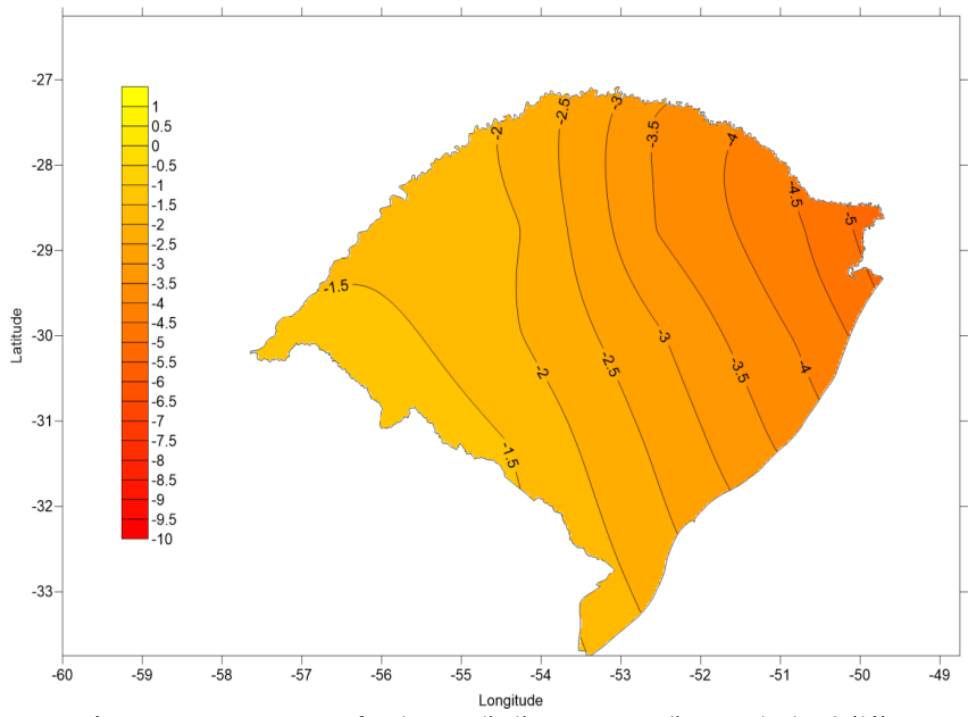

Figure 5. Averages of solar radiation anomalies $\mathrm{KWh} / \mathrm{m}^{2}(\%)$ Scenario 1 (2026 - 2050) 


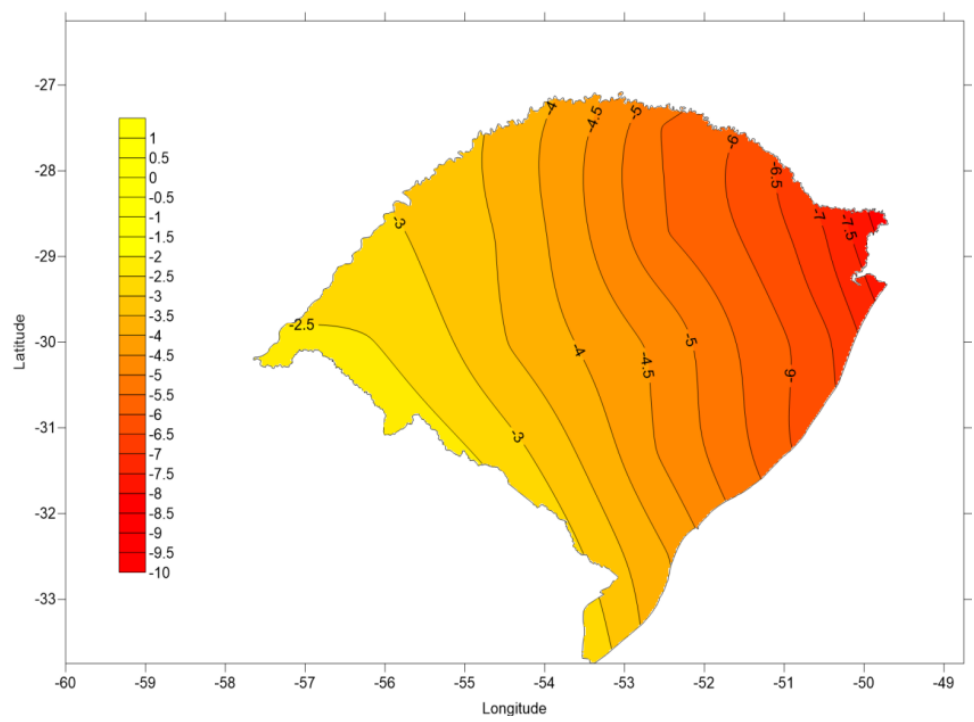

Figure 6. Averages of solar radiation anomalies $\mathrm{KWh} / \mathrm{m}^{2}(\%)$ Scenario 2 (2051 - 2075)

\section{Conclusions}

Renewable energies, for the most part, are dependent on weather conditions, so adequate energy planning requires climate change knowledge. The climatic projections, based on the pessimistic scenario, showed in all Rio Grande do Sul a solar radiation fall, reaching $12 \%$ in the eastern region of the state. This data demonstrates the need for concern with the factors that influence the pessimistic perspectives of this scenario, as it will directly affect a possible production of electricity from solar radiation. In order to diversify the energy matrix and minimize future climate impacts, it is important to invest in an energy policy considering renewable energy sources.

\section{Acknowledgement}

This research did not receive any specific grant from funding agencies in the public, commercial, or not-for-profit sectors.

\section{Referenes}

Buriol, G. A., Estefanel, V., Heldwein, A. B., Prestes, S.D., Horn, J. F. C. (2012). Estimativa Da radiação solar global a partir dos dados de insolação, para Santa Maria - RS. Ciência Rural, 42, 1563-1567,

Freitas, S. S. A. (2008). Dimensionamento de sistemas fotovoltaicos..Bragança: ESTIG, Dissertação de Mestrado em Engenharia Industrial.

Gross, J. A. (2015). Índice de Anomalia de Chuva (IAC) dos municípios do Rio Grande do Sul afetados pelas estiagens no período de 
1991 a 2012. Dissertação de Mestrado. Universidade Federal de Santa Maria.

Lima, R. A. (2012) .A produção de energias renováveis e o desenvolvimento Sustentável: uma análise no cenário da mudança do clima. Energy Law in Brazil, 5 (4).

Le Treut, H., R. Somerville, U. Cubasch, Y. Ding, C. Mauritzen, A. Mokssit, T. Peterson And Prather, M. (2007). Historical Overview of Climate Change. In: Climate Change 2007: The Physical Science Basis. Contribution of Working Group I to the Fourth assessment Report of the Intergovernmental Panel on Climate Change [Solomon, S., D. Qin, M. Manning, Z. Chen, M. Marquis, K.B. Averyt, M. Tignor and H.L. Miller (eds.)]. Cambridge, United Kingdom and New York, NY, USA: Cambridge University Press.

Silveira, S. S., Souza Filho, F. Martins, E. S., Oliveira, J. Costa, A., Nobrega, M. Souza, S. A. (2016). Climate change in the São Francisco river basin: analysis of precipitation and temperature. RBRH, 21 (2), 416 - 428

Sousa, M. M. (2010). Comparação Entre Ferramentas de Modelagem Unidimensional e Quasi-Bidimensional, Permanente e Não- Permanente, em Planejamento e Projetos de Engenharia Hidráulica. Rio de Janeiro, Brazil: UFRJ/COPPE.

Souza, E. B. (2004) .GrADS - Grid Analysis and Display System Fundamentos e rogramação Básica. Universidade Federal do Pará. Retrieved from http://www.dca.iag.usp.br/www/material/r itaynove/aca522/referencias/apostilagrad s.pdf>.

Van Vuuren, D. P.; Edmonsds, J.; Kainuma, M.; Riahi, K.; Thomsonm, A.; Hibbard, K.; Hurtt, G. C.; Kram T.; Krey, V.; Lamarque, J. F.; Masui, T.; Meinshausen, M.; Nakicenovic, N.; Smith, S. J.; Rose, S. K. (2011). The representative concentration pathways: an overview. Climatic Change, 109,5-31. 